\title{
THE SOVIETISATION OF ROMANIA, 1946-1948 - THE FIRST TWO YEARS BEHIND THE CURTAIN OF PROPAGANDA
}

\author{
CRISTIAN ALEXANDRU GROZA \\ Faculty of History, University of Bucharest, \\ Bd. Regina Elisabeta 4-12 Sector 5, postal code 030018, Bucharest \\ E-mail address: alexandru.groza@hotmail.com \\ Motto: \\ And Prometheus woke form his dream of power \\ as Gregor Samsa from Kafka's Metamorphosis. \\ L. Kolakowski (2009, p. 332)
}

@) $(\mathcal{Q} \Theta \Theta$

\begin{abstract}
Dogmatic discourse and institutionalized control build a totalitarian state on two main pillars: propaganda and indoctrination. Our study analyzes the phenomena of cultural mimesis and ideological transplantation inside the Romanian communist system. The periphery and centre represent concepts that help us in the process of constructing our cultural theory about the propaganda system and its evolution during the years before the abolition of the monarchy, 1946-1947. The study is based mainly on archive documents. Therefore, we followed up the chronological paths in which the propaganda was used as an external weapon, and also as an internal indoctrination.

Key words: The Great Romanian Hunger, communism, royalty, indoctrination, iron curtain.
\end{abstract}

\section{THE EAST EUROPEAN IDEOLOGICAL CONTEXT}

Dogmatic discourse and institutionalized control build a totalitarian state on two main pillars: propaganda and indoctrination. Our study analyzes the phenomena of cultural mimesis and ideological transplantation inside the Romanian communist system. Our academic study is constructed by extrapolating Hannah Arendt's (1994) analytic pattern towards a specific region and political context: the installation of communism in post-war Romania. Indoctrination and propaganda cannot be perceived as opposite (Arendt, 1994, p. 451), especially for the Romanian communists because it can be observed how their procedures intertwine. The propaganda is defined as a system used in the consolidation of social and diplomatic legitimacy through political speech, visual elements, written and oral manipulation of the public opinion. From an institutional point of view, the indoctrination is a process that involves a country 
centred policy, through which the communists created their path to supreme political power and, as a consequence, isolated Romania in the eastern bloc.

The study is based mainly on archive documents. Therefore, we followed up the two chronological paths in which the propaganda was used as an external weapon, to mask the absence of rights and the hardships of the country, and also as an internal indoctrination process that created mass education, proletarization, all of them being implemented through force and glaring disrespect to democratic values (Ivaşcu, 1998, p. 116). The Section of Propaganda and Agitation had a double standard position, by which we can analyze the external propaganda, facilitated through the communist oriented newspapers of the USA, France, the UK and Germany meant to nurture the idealist perceptions over Stalin's rule of terror over the East European countries. The second standard was an internal attribution of the Section of Propaganda and Agitation, which was well organized, at least from a theoretical point of view. It had a main role in the activities of censorship of newspapers, radio broadcasting, books and cultural events (Ilie, 2014, pp. 75-76).

The interest areas of the nomenclature inside The Section of Propaganda and Agitation (Ilie, 2014, p. 60) were very widely oriented because their main purpose was to integrate every social and cultural aspect in the process of forging of the utopian concept of the new man (Rostas, \& Momoc, 2007, pp. 33-34). The result is a scientific mythology (Boia, 2011, p. 220) which maintained the idea that hyper-technology and the evolutional process towards a perfect society represented the main purpose of the communist state. The Romanian Academy was among the first institutions that were brought under the communist party (Muller, 2003, pp. 105-107) and its goal was to encrypt the nonsense of the propaganda into a scientific and measurable social doctrine: "The totalitarian propaganda nurtures itself by escaping from reality into fiction, from coincidence into circumstance" (Arendt, 1994, p. 461). The identity of an individual became unrepresentative for the communist political system, so it was reorganized in a collective way by creating a pyramid formed of: proletariat, peasants and intellectuals. The last social category had the limited purpose of being the brain matter behind the wall of propaganda. The new reality was based on the information that was controlled by a tight political group, whose truth was built on mimetic procedures of implementation. Therefore, it remained only one way of understanding the world, the communist dogma (Hossu, 2007, p. 167).

\section{THREE SWORDS IN ONE SHEATH: HISTORICAL POLITICAL PARTIES, DEMOCRATIC SOCIETY, COMMUNISM}

The political changes from Romania, and also from the eastern European space, became a focal point for the foreign Occidental press, their purpose was to reflect, in more or less biased information, the real dimensions of the democratization process in the Soviet space. In 1946 The Times, the British new- 
spaper sent a correspondent to interview Gheorghe Gheorghiu Dej, of the Ministry of Industry at that time. The main topics concerned the economical sector, where the Russian intervention had left numerous casualties because of the high rated war debts. There was only one big question mark that was quite unclear: How will Romania act towards the western powers in this context? The answer given by the Ministry of Industry was defined by a strong propagandist content, which combined democratic arguments with socialist ones. Therefore the politics became a perfect screen through which the economic crisis was speculated to implement the interventionist state and the hard handed control over the society (ANR, CC al PCR, SPA, 89/1946, p. 3). The Times correspondent made a comparison for the transitional period, by putting together the consequences of the two regimes: Nazism and Communism, only because they had in common the process of choking the country of all its external independence. The economic agreement signed in 8th of May 1945, between Romania and the Soviet Union, was presented by the Ministry of Industry as a simple exchange of goods meant to create stability. In the answer regarding the external policy limitation, the same propaganda was used, by offering examples that did not cover the reality as a whole, just because Czechoslovakia, Poland, Bulgaria, Switzerland and France were used as a cloak to cover up the lack of possibilities. Eastern Europe was indeed affected by the Russian army and the Stalinist policy; those facts were undeniable even for Gheorghe Gheorghiu Dej: “The soviet authorities did not take anything important from the oil installations as booty. The only material that they took as trophy was the material used in the drilling process, from which, however a part remained in Romania and it is still used in the petroleum industry " (ANR, CC al PCR, SPA, 89/1946, p. 6). From this kind of speech we must observe a main aspect regarding the use of the relative clause did not take anything important, with the sole purpose to mask the reality in which the Romanian industry, agriculture and economy were completely paralyzed by the war debts and the control of the so called Sovroms. Their purpose was to ensure the implementation of the Kremlin's directives.

The external facts showed that the situation was more complicated then Dej's propagandistic statement because the country was thrown into an economic situation by which it had to transfer approximately $80 \%$ of its export goods towards The Soviet Union. There was no humanitarian or economic concern regarding the great risks that appeared in the society during the final stage of a war: hunger, high rate of child death, illness, and downfall of the democratic institutions (Deletant, 2010, p. 51).

The Communist Party of Romania did not want to risk its credibility so it took the road of collaboration with other political structures combined in The National Democratic Front. The game was to conquer power step-by-step through a Stalinist method: removing the opposition and gaining full control over the institutions. From a communist perspective, Romania was seen through a duality of political interests, the first one was based on socialism, so it was considered a progressionist force, and the opposition was defined 
as reactionary force (ANR, CC al PCR, SPA, 89/1946, p. 5). The last reference is clearly orientated towards historical parties of Romania: National Liberal Party and National Peasants Party. The main reason used by propaganda agents against them was the collaboration with Carol the Second and Marshal Ion Antonescu, as a consequence the only solution was to discredit their power centre inside the population, so they could be easily removed afterwards (ANR, CC al PCR, SPA, 16/1947, p. 73).

During the years between 1946 and 1949 the phenomenon of political cleansing was a general rule for the whole of eastern Europe, as a consequence the main political figures that represented the interwar democracy were removed from society by fake lawsuits or executions. An important puppeteer of all the communisation process, that took place in the liberated countries, was the soviet structure known as Cominform. It was put under the control of Andrei Jdanov, who was in power from 1947 to 1953 (Stran, 1998, pp. 65-66).

One of the most straightforward points of view was written by R. H. Markham, a journalist at the New York's New Leader newspaper. The article was entitled "The Romanian Masquerade" and published on 17th of April 1947 (ANR, CC al PCR, SPA, 6/1947, p. 8). Markham has a very detailed knowledge about the private lives of the Romanian communist leaders because he was the USA representative correspondent in Romania, during the interwar period (ANR, CC al PCR, SPA, 6/1947, p. 8). He stressed the fact that the entire region of eastern Europe is based on two major paradigms. The first one represents a system of power called Vişsinski's democracies, a mock term that refers to the absence of institutions and the abundant presence of soviet military occupation. The second paradigm is the process of enslaving the country's will by decapitating the intellectual elite, so the main consequence would be the creation of a moral void that could easily be brought under the communist propaganda (ANR, CC al PCR, SPA, 6/1947, p. 27).

Markham considered that Petru Groza was not a prime-minister with full authority because his role was to conceal the real intentions of the Communist Party from Romania, in fact of Gheorghiu-Dej, Ana Pauker, Vasile Luca and Teohari Georgescu, therefore his orientation towards communism was more likely to be opportunistic, rather than from belief. His portrait was always defined, from Markham's point of view, as a chameleon politician who survived during the National Legionary State and the rule of Ion Antonescu and he even managed to obtain goods and houses that were in the property of Jews (ANR, CC al PCR, SPA, 6/1947, p. 8). Even Gheorghe Tătărescu entered in the cynical perspective of the American journalist; he was seen as an able politician who earned his position as Minister of Foreign Affairs because of his experience in skewing the elections during the rule of Carol the Second. Another figure was Lothar Rădăceanu, the Minister of Work, who had close relations with some of the Nazi officers through his watchmaker experience. His socialist party friend Ştefan Voitec was responsible with the military propaganda during Antonescu's years. Mihail Ralea, the Romanian Ambassador in USA, had an important role in creating a false democratic image for his 
country, although he was fully aware of the problems that made the Romanian people suffer (ANR, CC al PCR, SPA, 6/1947, p. 9). This brief presentation of the new type of politicians outlines the hypocrisy of the communist hybrid power, which balanced between compromise and political adaptation through propaganda discourse.

\section{THE GREAT HUNGER - EXTERNAL HELP AND INTERNAL PROPAGANDA}

The Marxist perspective showed that the working force, the so-called proletariat, had the purpose to speculate every context as a path towards to the authority growth of the Communist Party. The main victims of this sort of pragmatic thinking were the peasants because they were always in an unstable context of poverty and expropriation (Kolakowski, 2009, p. 243). The proletariat was the main source of social revolution; therefore it had to use every aspect of the political and economical crisis, and even to maintain them, in favour of their ideological system.

During 1946 and 1947 the Great Hunger (Cioroianu, 2005, pp. 71-72) affected mainly Bessarabia, Moldavia and also parts of southern Romania. The initial phase of development was masked through propaganda, but once with the Swedish humanitarian help the alimentary crisis became a subject of international concern. The Romanian Legations had to admit the reality only in external speech, but from an internal point of view, the indoctrination process used the context to attack the bourgeoisie and the capitalist system blaming them for the famine. Sovrom corporations and the war debt towards Soviet Union were not even mentioned in the official discourse (Lache, 2010, pp. 320-321), the sole purpose of these omissions was to create a positive image for the Romanian Communist party.

Only the external perspective of Erik Kinberg represented, at that time, the real situation of the humanitarian problem, the propaganda was trying to conceal the evidence of the high number of deaths. Only after eight months of suffering the problem became well-known to the Western press and also because the Prime Minister Petru Groza and the Central Committee of the Communist Party from Romania were forced to admit the famine through special permits accorded to Romanian Legations (ANR, CC al PCR, SPA, 16/1947, pp. 3-5). In November 1947, Eduard Mezincescu sent an internal document that was elaborated for Ana Pauker, the Minister of External Affairs. The information in the news report was gathered by the Romanian Legation from Stockholm and contained the official standpoint over Romania. Mezincescu considered necessary to mention, in the briefing, that all the reports contained defamatory content for the real democracy from Romania (ANR, CC al PCR, SPA, 6/1947, p. 1).

For the year of 1947, the newspaper Aftonbladet had the most relevant coverage about the Romanian hunger, and presented, in detail, every finan- 
cial and material effort made by Bulgaria, Hungary, Czechoslovakia, Sweden and UK. The USA were, at that time, blocked in the procedural decision of Congress because of their concerns regarding the real final destination of the help products designated for Romania, the Soviet Union. Considering the fact that the American bureaucracy would take a long time of decision before entering in the humanitarian campaign, Gen. Marshall, as Minister of Foreign Affairs, took the initiative to transfer approximately 7.000 tons of cereals, which were stocked in the warehouses of the American troops sent in the Mediterranean area. The main reason behind his act was the information that showed the country's final resources would be consumed by the end of March. Romania was not able to pay for the shipment, so it was the direct responsibility of the Red Cross to use its funds the buy the allocated food and ensure the process of transfer to the affected population. The second transfer was made through the help of Sweden, which lobbied its status of guarantor in front of the South American States; therefore encouraging a transfer of 27.000 tons of corn (ANR, CC al PCR, SPA, 6/1947, p. 5).

During the toughest period of the famine, from March 1946 to April 1947, which was doubled with outbreaks of tuberculosis, sexually transmitted diseases, scurvy and malaria, Romania had a total population of 16 million people, from which more than one million were suffering from hunger or illness. The rate of child death reached $100 \%$ because a lot of new mothers or families moved from the affected areas and abandoned their children, leaving them behind because they did not have any means of taking care of them anymore. The reports signed by the coroners mentioned that the Romanians had completely changed their usual diet and turned to non-edible resources, most of them were not even digestible: textile materials, wood, earth, hay, clay. Bread was rationed to 250 grams per day, but this was mentioned only in the official reports of the government, in fact, the supplies were transported twice a month, during winter times they were delayed to more than a month or so. The health status of the population was aggravated by the tuberculosis problem, which affected more than 800.000 people, from which 500.000 died in a few weeks. Approximately 38.000 cases of exanthematic typhus reduced the life expectancy more than a half; children and elder people were mainly affected. In less than a year, the pyramid scale between children and adults had reached a dramatic status: for 2.000.000 adults there were 250.000 children (ANR, CC al PCR, SPA, 6/1947, p. 6).

On 20th of March 1947, Aftonbladet published a critical article aimed at the Romanian government, based on the experience accumulated during the help mission. The actions of the Swedish help were coordinated by Karin Reutersward, the wife of the Swedish ambassador in Romania, therefore Glunnar Muellern, the author of the cynical standpoint who interviewed her, thought it was needed to portray Mrs. Reutersward as "the Swedish women who is the angel of Romania". Her main arguments referred to Romania as a "catastrophic country", being affected "by the worst suffering since the Middle Ages up to our times" (ANR, CC al PCR, SPA, 6/1947, p. 2). 
Moldova was the worst affected because of the high rate of depopulated villages and the inevitable failure of the agrarian reform. Most of the peasants had been forced to give up their land for a minimal amount of food, based on the principle "one sack of corn, one hectare of land" (ANR, CC al PCR, SPA, $16 / 1947$, p. 42). In Iasi the trains were full of refugees, sadly most of them died on their way to the city, being unfed and ill. The number of deaths was alarming and the weak reactions from the Communist Party were concerning for the soviet power and, for this reason, the Romanian leaders received permission to create CARS. The acronym came from The Help Committee for Droughty Areas; in fact, it represented a controlled institution that had the role to create a propagandistic appearance of involvement (ANR, CC al PCR, SPA, 6/1947, p. 4).

Many of the deceased were not buried, due to the interdictions coming from the Romanian Communist Party. The purpose was the decrease, in an artificial way, the real number of deaths, as a consequence the priests were not allowed to attend or organize funeral prayers. The medics were obliged to create fake death certificates by mentioning the reason of death as chest illness instead of inanition. In these chaotic circumstances, Gheorghe Tătărescu realized the critical breakdown in which Romania felt after 1944, and with a last attempt of using his status of collaborator he tried to persuade the USA to intervene (Lache, 2010, p. 290). His effort to contact the American Legation of Romania was perceived as a personal scheme to save his own life, therefore the New York Herald Tribune attacked, in a blunt way, the actions of the Romanian minister: "the American Legation from abroad does not enter in this sort of suspicious thing and also because the American do not want to enter in any sort of contact with Tătărescu" (ANR, CC al PCR, SPA, 6/1947, p. 21).

\section{A DIRECTED VICTORY- THE FALL OF THE CURTAIN}

The last considered enemy of the communist regime was King Michael of Romania. From a historical point of view the royal institution was considered incompatible with the proletcultist image of the new mankind and the new type of society. Everything that had a symbolical value for the Romanian royalty was connoted with terms like bourgeois, landowner abuse, citadel of corruption. The Communist Party from Romania thought that the presence of King Michael and Queen Helen of Romania, his mother, corrupted the journey towards the democratic values that Ana Pauker, Teohari Georgescu and Vasile Luca tried to implement under soviet control; therefore the propaganda used their image against them, hoping to create a massive counter-reaction towards the monarchy. The final blow that deconstructed the last institution that could guarantee a possible return to democracy was in 30th of December 1947 (Tănase, 1998, p. 82); from this moment every political evolution and intellectual progress, constructed during the interwar period, was brought under ideological control. In the first days of the year 1948 Romania changed 
its status, from constitutional monarchy to Socialist Republic of Romania and the Communist Romanian Party transformed itself in the Romanian Worker's Party (PMR).

For a new context there were needed new forms of interpreting recent history, as a consequence the propaganda had to adjust its current instruments and by implementing harsher methods of manipulation towards public opinion. The first step was to discredit the evolution of the modern Romania, by emphasizing the criminal role of the monarchs, which were presented as responsible, from Carol the First to Michael, of despicable acts through different moments in time: the 1907 uprising, the strike from $13^{\text {th }}$ of December 1918. With the last two kings, Carol the Second and Michael, the propagandists used their actions to show that Marxism and Stalinism can be applied successfully also in Romania, by eliminating the negative relation between the exploiters and the exploited; a relation which was brought by the connection between Nazism and monarchy (Focşeneanu, 2014, p. 53). The abdication of King Michael created enough space for the full propaganda and indoctrination processes to unwind against a whole negative category: the war criminals. In it every person who had obtained a social status before 30th December 1947 was considered a potential collaborator. Marxism proved to be a political ideal but with weak roots in the Romanian mentality, so the only way to implement it was by force, using the power of the state to manipulate and control through terror and indoctrination.

The first parliamentary session was organized comprising a restricted number of participants, aimed at the shifting of the state's legislative power towards the Assembly of Deputies. A new status had to be sustained by a fundamental law, so a Legislative Constituent Assembly was founded with the mission to generate, as soon as possible, the new socialist Romanian constitution. The leading figures were Constantin Parhon, "a great scholar and a faithful fighter for democracy", Mihail Sadoveanu, "a great writer", Ştefan Voitec, general secretary of the Romanian Democratic Socialist Party, alongside Ion Miculi "a veteran of the working class movement in Romania" and Gheorghe C. Stere, the president of the Romanian Court of Appeal. From this moment every reform that was initiated had a clear way to the Parliament, Romania being caught definitely inside the "fight of the democratic camp against the Anglo-American imperialism". (ANR, CC al PCR, SPA, 16/1947, p. 68).

The communists were aware of the fact that the masses were used only to propagandistic value because, in reality, the situation was completely different "[...] we have to raise the masses of workmen to higher ideas [...]. This is very hard to do with the masses, without transforming our slogans into demagogic ones, into reformist chatter" (ANR, CC al PCR, SPA, 9/1948, p. 27). This fragment of realist discourse was elaborated by Leonte Rautu, and shows how the Romanian society was regarded as a whole, respectively how the question marks regarding the real success of the propaganda and communism in Romania were concerning the leaders. The construction of the 
propagandistic effort was concentrated, mainly, on the ideological stakes and rarely on the public, so it was needed to create a speech that could be easily understood by the mob, which was, from the perspective of Răutu, completely uneducated. In the post-war society it can be observed how communism constructed Romania, during 1948 and 1953 through an ultra-traditionalist perspective, based on the influential Stalinist dogma. The local identity was diminished in the favour of an internationalist soviet culture, which means that the Socialist Republic of Romania transferred its whole identity content to the limited perspective of Marxism-Leninism and proletcultist mentality.

The dominant culture and the inspirational pattern of the intellectual conduit were based on the propaganda elements imposed by the Soviet Union, which became a universal standpoint for every scientific domain, from animal breeding to complex logical systems. The propaganda used in the process of counterfeiting an image of stability changed fundamentally after the abdication of King Michael of Romania, but also became faultier in its praxis because of inconsistent or demagogical use of its instruments (ANR, CC al PCR, SPA, 9/1948, p. 106). The reality was undeniable because the system, which came into force after $23^{\text {rd }}$ August 1944, was mainly generated by the soviet occupation "The Communists would not have been the rulers of the Romanian state; at least, not in a short period of time and obtain such results to create a popular republic, to banish a king without the help of the Soviet Union"(ANR, CC al PCR, SPA, 9/1948, p. 105).

The purpose of the ideological factor was to forge a common conscience capable of being easily integrated into a new identity pattern (Bataille, 2008, pp. 75-76). It was necessary to invent a communication bridge between intellectual and simple citizens, with the sole purpose to cancel any social and educational differences inside the social classes, so the role of the elite was to transfer all its values into communist ideology and become the voice of the masses "constructing one whole cultural and social block" (Gramsci, 2001, p. 51). From a theoretical point of view, in the year 1948, the Romanian Worker's Party had approximately between 3.000 and 6.000 community centres that were used as main propaganda mechanisms (ANR, CC al PCR, SPA, 9/1948, p. 111). The pressure over the Section of Propaganda and Agitation became very harsh because its attributions had tripled in less than three months. Therefore its responsibilities were: organizing conferences for the Party, press control, implementing the system of wire broadcasting, censorship of any kind of cultural program. Everything was reduced to a basic pragmatic need, to ensure that all the cadres were perfectly functional in every type of indoctrination process. The psychological profile of an agitator was given by a complex set of moral (Rostas, \& Momoc, 2007, pp. 76-77), political and social features that conferred him "a pleasant behaviour and a good social situation" (ANR, CC al PCR, SPA, 9/1948, p. 115).

The agitator should not have a criminal record, violent behavioural, or other negative aspects like being a womanizer or alcoholic, he had to be in a good physical shape, and especially educated at the Communist Party's 
schools. The role of these mixed paradoxical features was meant to create a new type of human, which could generate the respect of the masses and could be used as a propaganda model for the whole society.

\section{CONCLUSIONS - CAPTIVE ROMANIA, A REALITY}

The contexts in which the communist ideology expands are based on three main criteria: press, radio and conference. The element that confers unity to the propaganda efforts consists of the ability to have a permanent control over the informational flux. No matter what manipulation techniques were used in the political speeches of Pauker, Dej or Groza, the essence of their allocutions was based on the Stalinist dogma and the firm application of the communisation process.

According to Gouldner's theory (Gouldner, 2001, p. 284) a cultural pattern always starts from the ideological centre and spreads to the peripheral areas, so the model is exported and modified as it evolves in a certain context. To be more specific, the aspect on which we are focused is the concept of nomenclature, which evolved differently, but used the same methods of forging: the Party's indoctrination schools, which created a new mentality of individuals with limited intellectual possibilities. Nomenclature represents the pillar of the whole communist ideology and guarantees its functionality, inside it there are multiple types of individuals, from pure breed intellectuals that converted to communism, to the basic working man. All of them have the same purpose: the monopolization of truth and the process of implementing the soviet mimesis.

C. Wright through the theory of the cultural apparatus (Gouldner, 2001, p. 288), offers a valid instrument of analyze because it defines the central concepts that assure the functionality of the propaganda system. Every kind of scientific, intellectual or artistic activity that is created by, or for, the educational backgrounds: radio, theatre, press and school can be considered a part to the cultural apparatus, which acts under a constant planning and dogmatic pressure. The manipulation of the conscience of the masses becomes the only way of survival for the communist elite, so the options of the new political system march into a specific balance that involves terror and control. For the post-war Romania we have a dual image of the communist power because there are two worlds. One of them is created by propaganda and represents the Romanian Workers Party as a perfect cultural apparatus, and the second one is faulty, although it has members that were trained at the ideological schools A. A. Jdanov (Ilie, 2014, pp. 155-156), Ştefan Gheorghiu (Tismăneanu, 2008, pp. 161-162). The final result is an unclear centre of power which expands its authority by a constant process of redefining: "As long as a group of power can reproduce itself or it can forge a social conscience, it would not create any internal logic inside the system that would determine someone to wish his own (political) death" (Gouldner, 2001, p. 292). 
The result was a paradoxical one, mainly because the identity was constructed through propaganda stereotypes; therefore, the term class conscious embodied what Czesław Miłosz defined as the captive mind (Miłosz, 1953). The linguistic paradigm and the dogmatic relevance created a humble status for the common citizen, by becoming a victim of imprisonment, daily abuse from the communist authorities and also an overwhelming control of the state in every sphere of private or public life. The purpose of this social experiment and procedures was to ensure the standardization of the individual to a certain defined pattern: the new human being, adapted from the concept of homo sovieticus.

The most efficient weapons, inside this process of social enculturation, consisted of the events that used a scientific and cultural pattern combined with the process of indoctrination, and the final desired result should have been measured in the effectiveness of the human soul's engineers actions. This metaphor was used by Stalin to define the Communist Party's members that were involved in propaganda and education. The consequence of all this processes generated a fake memory and identity for the nations that entered under the soviet control (Kolakowski, 2010, p. 86), for instance the case of the final years of King Michael of Romania offers a good example. Until the year of 1947 the image of the royal figure was tolerated in public appearances alongside the portrait of Stalin, but after the forced abdication every aspect that reminded about the communist collaboration with the king was censored, destroyed or counterfeited. The public opinion had to forget its recent history and see events only thorough the official channel of propaganda (ANR, ARLUS, 47/1946). The post-war Romanian society was not eager for an egalitarian system; it desired a real solution that would resolve the problems created by the consequences of the war. The Romanian Workmen's Party falsified the democratic representativeness by putting forward the model of a false friend, the Soviet Union

Was the doctrinal mimesis a real state of spirit between the so-called tough line communists, who promoted the Marxist concepts? The answer is not easy to find, but through a thorough analysis of the archive documents we can understand that the whole process of communization brought forward a complete set of dogmatic manoeuvres, which involved nomenclature members, agitators and propagandists that had the purpose of creating legitimacy for the new political system (ANR, Gheorghe-Gheorghiu Dej Collection, 685, pp. 10-11).

The Soviet Union was the engine that determined all the major changes inside the communist bloc, and the power of Stalin was not a stable or predictable evolution, therefore the rules of the game were in a permanent reconfiguration. For this reason after 23rd of August 1944 the main tactic was to implement a fake democracy by forging a party union that had a transitional value, formed out of communist and the historical parties. Once the purposes where reached, especially during 1946 and 1947, the eastern communist camps closed their gates and the totalitarian regimes took away their masks, exposing their real intentions by an absolute control over the captive societies (Chiper, Constantiniu, \& Pop, 1993, pp. 101-107). 
None of the cultural aspects escaped from the integrative Marxist and Stalinist perspective of Andrei Jdanov, through which the class consciousness of the proletariat had to prevail in art, literature and science; all Western values were presented as decadent and the only viable culture remained the one promoted by socialist realism. If from a political level the masses were not so well represented, from scientific and artistic context the demagogy had to be complete. The core of any kind work that could be exploited publicly had to maintain a collective value, by removing any sort of individualism.

The attitude of the communist power can be defined as a product of the nouveau riche culture (Kolakowski, 2010, p. 120), where the elitism was redefined through mediocrity brought up as class identity. The Soviet Union imposed a control by using every means of force and political benefit to eliminate even the communists who were hard line on the Marxist Leninist views, making spaces for the new type of nomenclature of healthy origins, but with serious intellectual gaps. The immediate result was an aberrant easement towards Stalinism and an irreconcilable hateful speech against the real intellectuals marginalized inside the system. The inabilities of the Central Committee of the Romanian Working Man's Party to control the local initiative were, most of the time, a factor of tensions between the communist structures. The party does not present itself as a militarized structure, with firm monolithic functions, but rather as an inconsistent game of power and conflict between the communist rulers. This consequence, for the Romanian case, is a product of the identity reorientation in which the politics and the institutional attitude had to be recentred around the communist party.

The final stakes of the sovietisation process determined the defeat of the individual in the favour of a so-called collective good. Democracy, freedom and human rights became unrepresentative for the basic human need. With the new type of humanity the communist regime offered to itself everything that was needed for a totalitarian world controlled by the utopian dogma. From a Stalinist logic, political values created only a one way revolution, so the Marxist road became the purest expression of violence as a base for the perfect state. Stalin and his European disciples forgot one thing that neglecting the human life and intellectual value was just a step in Marx's perspective and not a permanent state of existence.

\section{ABBREVIATIONS}

ANR- Arhivele Naționale ale României [Romanian National Archives]

ARLUS - Asociația Română pentru Strângerea Legăturilor cu Uniunea Sovietică [The Romanian Association for Tightening the Bonds with Soviet Russia]

CARS - Comitetul de Ajutorare a Regiunilor Secetoase [The Help Committee for Droughty Areas]

CC al PCR - Comitetul Central al Partidului Comunist Român [Central Committee of the Romanian Communist Party]

PMR - Partidul Muncitoresc Român [Romanian Worker's Party]

SPA - Secția de Propagandă şi Agitație [Section of Propaganda and Agitation]

SOVROM - Mixed Romanian-Soviet Economical Societies 


\section{ARCHIVE SOURCES}

ANR, CC al PCR, SPA: 89/1946.

ANR, CC al PCR, SPA: 16/1947.

ANR, CC al PCR, SPA: 6/1947.

ANR, CC al PCR, SPA: 9/1948.

ANR, ARLUS: 47/1946.

ANR, Gheorghe Gheorghiu Dej Collection, 685.

\section{REFERENCES}

[1] Arendt, H. (1994). Originile totalitarismului [The origins of totalitarianism]. Bucureşti: Humanitas.

[2] Bataille, G. (2008). Partea blestemată [The damned part]. Bucureşti: Editura Art.

[3] Boia, L. (2011). Mitologia ştiințifică a comunismului [The scientific mythology of communism]. Bucureşti: Humanitas.

[4] Chiper, I., Constantiniu F., \& Pop. A. (1993). Sovietizarea României, Percepții anglo-americane [The sovietisation of Romania, Anglo-American Perspectives]. Bucureşti: Iconica.

[5] Cioroianu, A. (2005). Pe umerii lui Marx [On Marx's shoulders]. Bucureşti: Curtea Veche.

[6] Deletant, D. (2010). România sub regimul comunist [Romania under the communist regime]. Bucureşti: Fundația Academia Civică.

[7] Focşeneanu, D. (2014). Două săptămâni dramatice din istoria României [Two dramatic weeks form the Romanian history]. Bucureşti: Curtea Veche.

[8] Gouldner, A. (2001). Ideologia, aparatul cultural şi noua ideologie a conştiinței [Ideology, cultural apparatus and the new ideology of the conscience]. In: J.C., Alexander, \& S. Seidman (Eds.). Cultură şi societate, dezbateri contemporane. [Culture and Society, contemporary debates] (pp. 284-297). Iaşi: Institutul European.

[9] Gramsci, A. (2001). Cultură şi hegemonie ideologică [Culture and ideological hegemony]. In: J.C., Alexander, \& S. Seidman (Eds.). Cultură şi societate, dezbateri contemporane. [Culture and Society, contemporary debates] (pp. 47-54). Iaşi: Institutul European.

[10] Hossu, L. (2007). Memorialul durerii o istorie care nu se învaț̆ la şcoală [The pain memorial a history that it is not thought in schools]. Bucureşti: Humanitas.

[11] Ilie, O. (2014). Propaganda politică: Tipologii şi arii de manifestare (1945-1958) [The politic propaganda: Typologies and areas of manifestations (1945-1958) ]. Târgoviş̧e: Editura Cetatea de Scaun

[12] Ivaşcu, L. (1998). Lavinia Ivaşcu. In: R. Rusan (Ed.). Anul 1948: Instituționalizarea comunismului [The year 1948: The institutionalisation of communism] (pp. 110-125). Bucureşti: Fundația Academia Civică.

[13] Kolakowski, L. (2009). Principalele curente ale marxismului (Fondatorii) [The main currents of Marxism (the founders)] (Vol. I.). Bucureşti: Curtea Veche.

[14] Kolakowski, L. (2010). Principalele curente ale marxismului (Prăbuşirea) [The main currents of Marxism (the fall)] (Vol. III.). Bucureşti: Curtea Veche.

[15] Lache, E.I. (2010). Statutul internațional al României de la război la pace [The international status of Romania, from war to peace]. Bucureşti: Editura Militară.

[16] Miłosz, C. (1953). The captive mind. New York: Vintage Books.

[17] Muller, J. L. (2003). Politică şi istoriografie în România, 1948-1964 [Politics and istoriography in Romania, 1948-1964]. Cluj-Napoca: Editura Nereamia Napocae.

[18] Rostas, Z., \& Momoc, A. (2007). Activiştii mărunți [Small party activists]. Bucureşti: Curtea Veche.

[19] Stran, C. (1998). A.A. Jdanov, Teoreticianul Cominformului [A.A. Jdanov, the theorist of Cominform]. Dosarele Istoriei 10(26). 65-66.

[20] Tănase, S. (1998). Elite şi societate [Elites and society]. Bucureşti: Humanitas. 